\title{
Climate resilient technological interventions to ensure food security in flood affected area - An experience from NICRA village, Dhubri, Assam
}

\author{
B. C. DEKA ${ }^{1 *}$, C. K. DEKA ${ }^{1}$, P. DAS ${ }^{1}$, J. GOSWAMI $^{2}$ AND H. C. BHATTACHARRYYA ${ }^{2}$ \\ ${ }^{1}$ Krishi Vigyan Kendra (A.A.U.), DHUBRI (ASSAM) INDIA (Email : ckdeka@ @ediffmail.com) \\ ${ }^{2}$ Directorate of Extension Education, Assam Agricultural University, JORHAT (ASSAM) INDIA
}

\section{ARITCLE INFO \\ Received : 22.04 .2017 \\ Revised : 14.09 .2017 \\ Accepted : 25.09.2017}

\section{KEY WORDS :}

Flood, Rice, Climate, Resilient

*Corresponding author:

Email : bhabesh_ch_deka@yahoo.co.in

\begin{abstract}
:
The study was conducted in villages of Dhubri district in Assam under National Innovation on Climate Resilient Agriculture (NICRA) project implemented by Krishi Vigyan Kendra, Dhubri during 2013 to 2015. The villages are situated under Bilasipara sub-division in the district 'Dhubri' of Assam, India on $26^{\circ} 15.425^{\prime}$ to $26^{\circ} 16.570^{\prime} \mathrm{N}$ latitude and $90^{\circ} 14.034^{\prime}$ to $90^{\circ} 18.040^{\prime}$ E longitude at an elevation of $128 \mathrm{ft}$ from mean sea level. Recurrent floods has been the principal constraints in food production in these villages affecting mainly winter (Kharif) rice during the growing season as well as summer rice (Boro and $A h u$ ) at the time of maturity. The prevailing weather patterns of the area were observed to have a strong bearing on the occurrence, intensity and magnitude of floods. About 71 per cent of total rainfall occurs during monsoon period (June to September), the winter being virtually dry leaving little scope for growing any Rabi crop. To ensure rice production to climatic variability leading to flood, site specific climate resilient technologies such as staggered planting rice variety 'Gitesh', flood escaping, short duration HYV rice 'Luit' for post and pre-flood situation, submergence tolerant rice variety 'Swarna Sub 1' and mid duration HYV of rice 'Joymati' during preflood situation were tested and demonstrated in the project villages. It was necessary to observe the performance of these varieties to the climatic vulnerability as well as farmer's acceptability. The average yield of the rice variety 'Gitesh' (45 days aged seedlings), 'Luit' (post flood situation), 'Luit' (pre-flood situation), 'Swarna Sub 1' and 'Jomati' were found to be 40 to $42,26.3$ to $36,23.35$ to $31.39,33$ to 45 and 42.37 to 50.76 q per hectare, respectively. As a result of the study and demonstration to endure recurrent flood and climatic variability, the newly introduced winter rice varieties, Gitesh has spread over the highest area in the project villages $(90.00 \%)$ followed by 'Swarna Sub 1' $(75.00 \%)$ and 'Luit' $(66.67 \%)$ due to flexibility in seedling age facilitating delayed transplanting, submergence tolerance upto 14 days and allowance for transplanting after recession of flood, respectively.
\end{abstract}

How to view point the article : Deka, B.C., Deka, C.K., Das, P., Goswami, J. and Bhattacharryya, H.C. (2017). Climate resilient technological interventions to ensure food security in flood affected area - An experience from NICRA village, Dhubri, Assam. Internat. J. Plant Protec., 10(2) : 442-447, DOI : 10.15740/HAS/IJPP/10.2/442-447. 